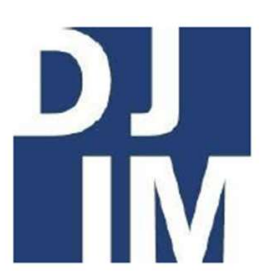

Volume 16

Spring

2021

ojs.library.dal.ca/djim

\title{
Public Perceptions of the Canadian Government's Initial Response to Coronavirus: A Canadian Broadcasting Company Content Analysis
}

Cora-Lynn Munroe-Lynds

School of Information Management, Faculty of Management, Dalhousie University

\begin{abstract}
It is crucial for the government to maintain the public's trust during uncertain risk. The Canadian government had approximately three months to develop a risk management strategy before Canada saw its first case of coronavirus. This study aims to show how the Canadian Broadcasting Company (CBC) portrays government decision making during the initial outbreak of Coronavirus in January 2020 through March 2020 exclusive by examining 10 articles per month. Over the course of the last three months, government officials were increasingly cited in the CBC news articles. Results from this study shows that as the condition in Canada worsened, more evidence-based decision making is present in the articles, especially during the month of March.

Keywords: Coronavirus, government decision making, public perceptions, covid-19 response, evidence-based decision making
\end{abstract}




\section{Introduction}

During a pandemic, the media plays a vital role in communication between government and citizens. The World Health Organization (2020) describes a pandemic as a new disease in which humans do not have immunity that spreads around the world (Miller, \& Zafar, 2020). A pandemic is classified as an "uncertain risk" which is when adverse effects cannot be accurately described however, the influencing variables would be known (Quigley et al., 2016). It is important to create trust between a government and its people during a pandemic because perceived citizens' trust (or lack thereof) of the government influences the rate in which the virus spreads in its country (Siegrist, \& Zingg, 2014). This study aims to show how the Canadian Broadcasting Company $(\mathrm{CBC})$ portrays government decision making during the initial outbreak of coronavirus in January 2020 through March 2020 exclusive by examining 10 articles per month. The research conducted for this paper answers three main questions.

1. How is the government's use of evidence for the coronavirus pandemic decision making communicated by the $\mathrm{CBC}$ ?

2. Do the $C B C$ articles sensationalize the coronavirus pandemic?

3. How do the articles perceive the Canadian government?
Section 2(b) of the Canadian Charter of Rights and Freedom states that Canadians have the right to "freedom of thought, belief, opinion, and expression, including freedom of the press and other media of communication" (Henry, 2013). The media has the right to cover any event the way they believe it should be told to the public. During a pandemic, this can be, and has been, very problematic for transfer of risk knowledge. There is a fine line the government and media can operate under in order to entice Canadians to follow health recommendations from the government while making sure not to cause unnecessary panic (Quigley et al., 2016). Risk communication needs to be addressed in multiple stages with considerations from experts in various fields such as policy analysis, law, sociology, communication, and psychology (Burns, \& Slovic, 2012).

\section{Literature Review}

How the government is depicted plays an important role in public perceptions of government initiatives during the coronavirus pandemic. If the government is depicted in a negative way, it can cause distrust in the government. The tone of the article in relation to the government greatly influences perceptions of the government; thus, tone is an important part of this study. To determine this characteristic and to create codes, phrasing and evidence was extracted from the articles. It is 
hypothesized that there is a correlation between phrasing in the article and how much - and what kind -of evidence is provided. How the government is depicted in the article is subjective, which has greater potential for biases than objectivity. Thus, phrasing that clearly shows a positive perception of the government was labelled as such. Depending on the location of readers and their political allegiance, a specific topic could be viewed neither positively nor negatively. For those reasons, tagging the articles as positive or negative would be directly influenced by my political allegiance. Moreover, articles that could not be identified for these reasons were labelled as "unidentified" or "mixed."

Themes regarding government initiatives and/or comments were recorded as being perceived as good or bad based on phrasing and context. The following strategies were used to determine perception of government:
a) Comparison between government decision making and evidence-based research;
b) Comparison between the Canadian government and other jurisdictions;
c) Economic and/or health support from the Canadian government;
d) Government action plan.

Risk knowledge, also known as hazard knowledge, and severity or importance of an issue are key players in public risk perception and trust of the government (Siegrist \& Zingg, 2014). That is why it is important to include probability data when communicating numerical information about a disease. Absolute data without probability data can lead to unnecessary anxiety because the consequences are communicated to the public without explaining the probability of someone contracting the virus. Not only should the government communicate the risk of being exposed to the virus, but representative of the government should also communicate how they have prepared for uncertain risk (Burns \& Slovic, 2012).

Broad narration boasts different responses from the public than individualistic narration. During a time of uncertain risk, frequent communication between experts and Canadians is imperative and the media is the link between the government and its people. Broad narration occurs when more than one person is depicted in an article; instead of focusing on an individual's death or illness, the focus includes the experiences of many people. Individualistic narration focuses on one person's illness or death. Reporting individualistic accounts, especially if there is a photo of the individual, causes greater emotional distress than a broader narration (Quigley et al., 2016). Understanding the context in which the information is situated 
will highlight whether the article is sensationalized.

For example, a 13-year-old Canadian died from H1N1 around the time when the vaccine was being distributed. Readers assumed that he was a healthy, normal boy in the photo attached to the article, which showed him smiling in his hockey jersey. The media caused magnified, deep grief and anxiety by exploiting emotions produced when grieving over a child (Quigley et al., 2016). The public's perceptions of uncertain risk are heavily influenced by whether a story is individualistic or a broad. Therefore, the focus (broad or individual) was recorded as well as the specific individualistic and broad coverage in each article.

\section{Methodology and Data}

\section{Extraction}

\section{Inclusion/exclusion criteria}

An analysis of the CBC's news coverage of the coronavirus was conducted. Articles from January $1^{\text {st }}, 2020$ to March $31^{\text {st }}, 2020$ were extracted randomly; however, the articles needed to meet a minimum criterion: the main subject of the article had to be regarding COVID19 in Canada and had to relate to the federal government. The scope of this research project focuses on the Canadian federal government; thus, provincial governments were excluded. Throughout the process of this study, it is noted that the health care system for each province is under the jurisdiction of the provincial government, not federal.

\section{Data collection methods}

For this study, a basic Google search was used under the header "news." When retrieving the articles, the search results were filtered by date. Three independent searches were conducted based on the dates. For example, the first search was for March 2020. The results were filtered between March 1, 2020 and March 31, 2020. Each search focused on the month in which the articles were published because it was difficult to find articles from January as there were an overwhelming number of articles from March. It is speculated there is a larger number of articles in March because, at the time of article retrieval, it was early April and coronavirus had increased substantially in Canada during the month of March. An even number of articles were collected per each month to determine how the Canadian government decision making was initially perceived in the media compared to the most recent month, March. The $\mathrm{CBC}$ articles were organized by month.

For the data extraction process, articles were chosen in monthly chronological order, then randomly selected for each month to minimize the risk of bias. By selecting articles in a random order, it is more difficult to create preconceived notions of patterns and trends. When collecting 
data, under the header "good or bad government," different themes were added and colour-coded based on good, bad, or neutral perception of the government. The following reasons led to ambiguous perception of the government: a) there was an equal number of themes classified as positive perception and themes classified as negative perception; and b) there were more themes classified as positive perception, but the title had negative connotations towards the government, and there were negative themes regarding government decision making.

\section{Coding Procedure}

During the coding procedure of the $\mathrm{CBC}$ news articles, six criteria were identified (figure 1). The Headline/Title of the article is the first piece of data to be coded. The headline of the article is recorded to understand how $\mathrm{CBC}$ wants the reader to feel before they even begin reading the article. The headline give insight into how information in the article will be presented. The headline of the article draws the attention of a reader. It is hypothesized that the tone of an article's headline has a direct relationship to the type of information provided. If the headline is objective, it is assumed that the information provided is also objective. If the headline is subjective with a negative connotation and/or is emotionally charged, it is hypothesized that the information provided in the article is sensationalized, boasts distrust in the government, and provides less evidence. Data about citations were used to determine level of evidence. Additionally, the headline of an article was used to determine how the government is portrayed in the article. 


\begin{tabular}{|l|l|}
\hline Criteria & Description \\
\hline Probability data & Is there probability data in the article? \\
\hline Absolute data & Does the article focus on the consequences and not probability? \\
\hline $\begin{array}{l}\text { Individual or broad } \\
\text { narration }\end{array}$ & $\begin{array}{l}\text { Is there individual identifying information or is the article situated in } \\
\text { a broader content? }\end{array}$ \\
\hline Perceptions of the & Is the government perceived as being good or bad? \\
\hline Citations & $\begin{array}{l}\text { Who is cited in the article (i.e., academics, scientists, government } \\
\text { officials)? }\end{array}$ \\
\hline Tone of Headline & $\begin{array}{l}\text { How is the article presented? What does the article want readers to } \\
\text { feel before they read it? }\end{array}$ \\
\hline
\end{tabular}

Table 1. Six criteria used to analyze the CBC articles.

Probability data is used to explore how the media perceives the level of risk for contracting coronavirus. Absolute data is also collected to determine if/what consequences are being highlighted in the media. The third category for coding determines if the article focuses on an individual's experience or the public. In the case of a pandemic, as seen with the SARS virus, individual experiences tend to have a higher rate of emotional response from the readers (Siegrist \& Zingg, 2014). Citations within the articles are coded based on who that individual represents (i.e., academics, scientists, government officials, civilian, etc.). The coding procedure began with articles published in the month of March. An article was then randomly selected, and the content of that article was coded. This step was repeated for the months of February, then January.

Probability data show how likely someone will contract coronavirus. Absolute data shows the consequence of the disease. This information is important to show the level of risk for contracting coronavirus, and the consequences. It is important that the media provide both absolute data and probability data. Probability data and absolute data together informs people about risk factors in contracting coronavirus, and the consequences that arise. This information, if communicated effectively, can encourage citizens to abide by emergency health restrictions and ease anxiety during a pandemic. 
Lack of probability data leads to articles that focus on the risk and consequence, which has the potential to increase anxiety and sensationalize the situation (Quigley, 2020). Numerical data relating to illness, recovery and death were used to identify and code articles with probability data and absolute data. Descriptors such as "deadly virus" were also used to determine probability and absolute data. The decision to limit the probability data and absolute data to health conditions was to promote consistency in the data so patterns and trends could be found. Probability data and absolute data provides evidence to answer the second question in this study: do the $\mathrm{CBC}$ articles sensationalize the coronavirus pandemic?

Citations from health officials, academics, and scientists help to maintain trust in the government because the public sees where the government is obtaining its evidence, and ultimately, provides greater transparency between the government and the public. When extracting data regarding citations, professional titles were recorded. This includes quotations from government officials, academics, and scientists in other countries. Adding quotes from professionals outside the Canadian government, allows us to see exactly what information is provided in the article. Moreover, this information provides strong evidence for finding consequential data and anxiety inducing sentiments.

Once qualitative data were extracted from the articles, the raw data was translated into descriptors (see appendix B). A list of code was developed based on the information in the descriptors. In an excel workbook, the articles were given codes (i.e., CBC-JAN-1). The codes assigned to the articles were based on the month they were published and were randomly assigned numbers between 1 and 10 . The article codes were then given descriptor codes for the following categories: headline, probability, absolute \& context, government perception, and direct/indirect quotes. From there, I was able to determine trends and patterns in the data.

\section{Results}

Of the 30 articles, five (2=January, 2= February, $1=$ March) were excluded from this study because there was no evidence in the article indicating perception of the federal government nor was there any indication of evidence-based decision making by the federal government. Of the 25 remaining articles, the perception of the government in two articles is inconclusive due to variables including tone of headline and perceived perception of the government. There are significantly more articles that perceive government decision making as positive. 
Table 2. Perception of the Canadian government decision making during the initial months of COVID-19 in Canada

\begin{tabular}{lllllll} 
& & Mixed & - & Mixed & - & Grand \\
Row Labels & Positive & Positive & Undetermined & Negative & Negative & Total \\
\hline January & 7 & 1 & 0 & 0 & 0 & 8 \\
\hline Feb & 4 & 1 & 1 & 1 & 1 & 8 \\
\hline March & 5 & 1 & 1 & 0 & 2 & 9 \\
\hline Grand Total & $\mathbf{1 6}$ & $\mathbf{3}$ & $\mathbf{2}$ & $\mathbf{1}$ & $\mathbf{3}$ & $\mathbf{2 5}$ \\
\hline
\end{tabular}

Seventy-six percent of articles in this study included direct or indirect quotes from scientists, professors in the field of medicine, or someone from the Department of Health Canada. As coronavirus spread throughout Canada, the CBC articles contained more direct and indirect quotes form various government leaders about the evidence they used to make decisions; March had the most quoted experts.

Four articles perceived the government as negative and two were undetermined. As seen in figure 1 , only $21 \%$ of articles with positive government perception also had a reassuring headline. In January, there were more articles that had an alarming headline than in February or March. Figure 1 shows the type of headline that is associated with articles that perceive the government in a positive way. Articles that were mixed but mostly positive and articles that had a positive perception toward the government are included in this graph. As seen in figure 1, there is one more alarming headline in January than in March. Moreover, January seemed to have more headlines that have a mix of reassuring and alarming connotations than in February, As the months went by, more articles had reassuring headlines. 


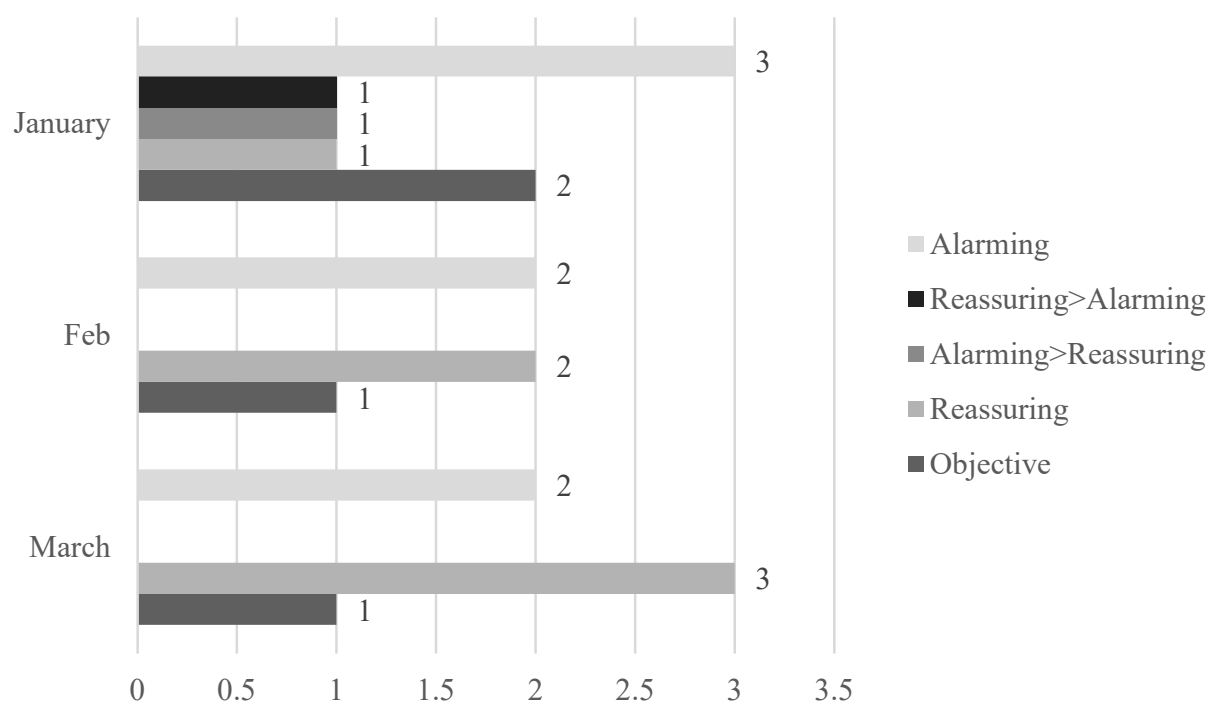

Figure 1. Headline sentiment for articles that perceive the government as positive.

However, figure 2 shows the overall probability data associated with the articles. As you can see, probability data is only stated in one article. Most articles that provided probability data requires the reader to calculate the probability of getting sick. As time goes on, probability neglect occurs more frequently in the articles. Nine articles had no probability and of those nine, six also had no absolute data. Only one out of 25 articles had numerical probability data that the readers did not have to calculate themselves. $57 \%$ of the articles that mention probability required the readers to find the numerical data in the article and do the calculation themselves or they mention minimal risk in passing. No articles focused on probability data.

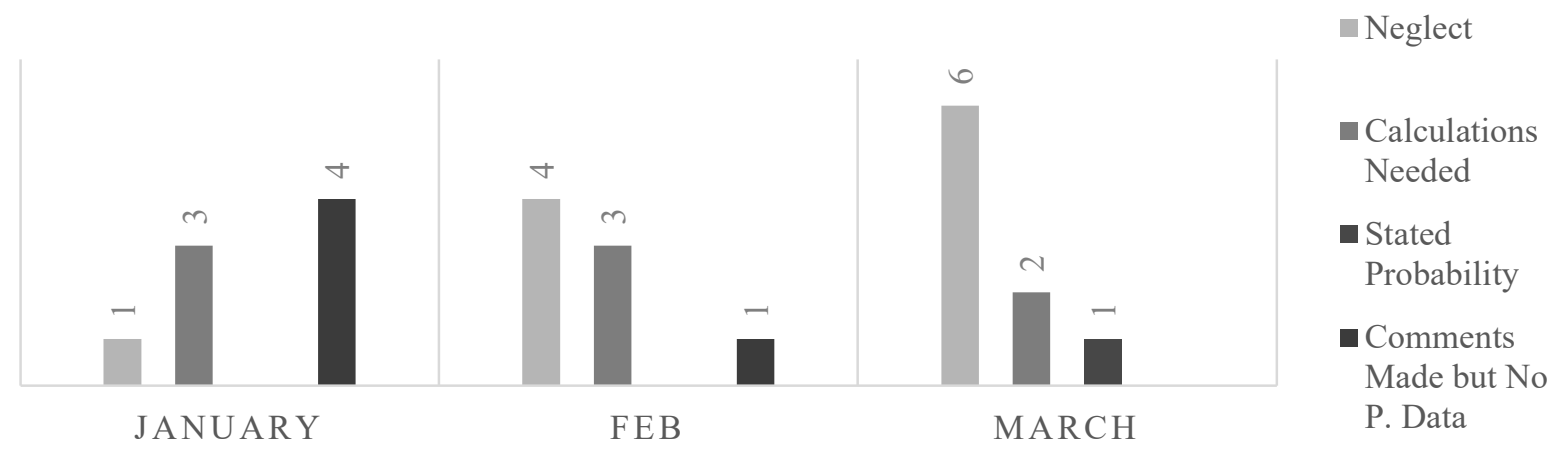

Figure 2. The number of articles that contain probability data. 


\section{Discussion}

Overall, the government seems to be perceived in a positive way based on the evidence in this research. A broader context was usually used, which substantially minimizes the amount of anxiety induced by the articles. Since there were only travel related infection in Canada in January (Harris, 2020), articles published in January focused on how prepared the government was to combat mass infection in Canada. By February, the main concern was getting Canadians out of infected areas. The negative comments about government decision making during the month of February were about not allowing Canadians who test positive with COVID-19 to board planes to return to Canada from China. However, every article that mentions leaving Canadians behind also commented on consular support and financial assistance; all articles with negative comments regarding Canadians abroad included positive comments as well.

Every article in January gave a positive perception of the government; one article had negative connotations towards the government but the general sentiment about the government was positive. All but two articles in January included direct quotes from one or more government officials. The two articles that had indirect quotes were also situated in a broader context, the headlines were alarming, and they both had comments about minimal risk. No articles in January focused on individuals; however, two commented about individual Canadians. These articles were related to Canadians aboard that were trying to get home. Most articles in February that focused on individuals spoke of people that were on the Diamond Princess cruise ship in Japan. Even the articles that focused on individuals abroad, for the most part, they also included basic information about the virus. Typically, the articles that mention Canadians aboard focused on the government efforts to bring them home. For example, an article published on February 15,2020 describes how the government planned to send a charter plane to Japan. In this article, there is a direct quote from the Foreign Affairs Minister of Canada and Health Minister of Canada ensuring that the government is "working closely with Carnival Cruise lines and the government of Japan to assist in this evaluation" ("Federal government to bring home Canadians," Feb 15, 2020).

Three articles in this study were classified as anxiety inducing because they all had an alarming headline, probability neglect, and the government was presented in a negative tone. As mentioned in the methodology section, negative perception of the government and 
probability data both contribute to a decrease in trust in the government and increase in anxiety. The articles that were anxiety inducing occurred in February and March. As seen in figure 2, as time goes on, less probability data is seen in the articles. At the end of February and into March, the government had been urging people to take precautions such as wearing a mask and social distancing. It could be possible that the lack of probability data was a way to encourage people to follow suggested precautions, however, this is undetermined. Further research will need to be conducted to understand if there is correlation between probability data and efforts to get the public to follow general precautions.

Additionally, eight per cent of the articles focused on individuals rather than a broader context. As mentioned by Quigley et al (2016), articles that focus on individuals cause greater emotional distress than articles that focus on a larger population of people. Of those articles that focus on that contain individual experiences, they also contain broader information. Moreover, the individuals are part of a larger story and was not the main focus of the article.

Every article from February was situated in a broader context; four articles mention individuals. Half of the articles written in March had no probability data, while the other half either mentioned minimal risk or the reader must calculate the risk level. February had more articles that perceived the government negatively than January and March combine. In February, most articles focused on bringing Canadians back to Canada from abroad. The Foreign Affairs Minister worked with the Government of China to get Canadians who tested negative out of China, and worked with the Japanese government to bring Canadians who were stranded on the Diamond Prince cruise ship that tested negative home ("Federal government," 2020; “Flight carrying Canadians," 2020).

In March, two articles perceived the government as negative. One article indirectly quoted the Prime Minister of Canada while the other quoted the Prime Minister directly; neither article includes quotes from other people. The Prime Minister was cited in all but two articles in March. Prior to March, the Prime Minister was only cited in one article in both January and February. Additionally, 55\% of content in March had no absolute or probability data.

This study suggests that $\mathrm{CBC}$ reported about coronavirus in a way that minimized anxiety levels. Additionally, the CBC kept public trust in the government by reporting government decision-making in a positive tone with direct evidence through citations from government officials and experts in virology, immunology, and medicine. $\mathrm{CBC}$ refrained from using an 
individualistic narrative in the same way it was used during H1N1 crisis when the 13-year-old boy died. Prior to the death of Evan Frustaglio, vaccine demand was low (Quigley et al., 2016). Once media articles across Canada used an individualistic narrative when reporting the death of Evan Frustaglio, vaccine demand surged. The demand for a the H1N1 vaccine was the highest for any vaccine produced.

CBC took a different approach to addressing the coronavirus pandemic. CBC articles focused on helping the Canadians financially, helping Canadians abroad to return to Canada, and reporting on safety measures implemented by federal and provincial governments to minimize the risk of infection for Canadians. In January, most of the articles were categorized as being positive; however, there seemed to be more skepticism towards the government in January due to contradictions between claims made by the Chief Medical Officer and the World Health Organizations.

It must be noted that, this study is an example of media perceptions of the Canadian federal government, and that responsibility for health care is shared between the federal and provincial governments. Moreover, this study is an example of media perceptions rather than a comprehensive content analysis. More research that includes provincial and federal government coverage is needed to fully understand media perceptions of government decision making during the coronavirus pandemic. Even then, one must be careful not to generalize health care decisions because the provincial governments unevenly spread responsibility across regions, thus creating many challenges including unfunded mandates, issues with data ownership and sharing data, and external forces (Quigley et al., 2016).

\section{Conclusion}

By March, the Canadian government urged people to stay in their homes and only go out for essentials as more provinces declared a State of Emergency and issued self-isolation regulations (Cecco, 2020). Abrupt change and job loss caused anxiety among citizens; it is crucial that the government communicates effectively in order to maintain order and ensure compliance during uncertain risk (Burns \& Slovic, 2012). Evidence from this study suggest government officials and health science experts were quoted more in the articles because they are communicating frequently to ensure Canadian citizens are compliant with social distancing advisory from the Federal government. Additionally, communication between the government and its citizens promotes transparency and trust in the government. From January $1^{\text {st }}, 2020$ to March 31 ${ }^{\text {st }}, 2020$, government officials were increasingly cited in the $\mathrm{CBC}$ news articles. The evidence suggests this 
is the case because the growth rate of the disease has exponentially increased from no cases in Canada to at least one case in every province and most of the territories. As the condition in Canada worsened, more evidencebased decision making is present in the articles, especially during the month of March when provincial governments started implementing social distancing regulations.

Lack of probability data when there is a large volume of consequential data (absolute data) contributes to the mounting anxiety caused by uncertain risk like a pandemic (Burns \& Slovic, 2012) (Burns \& Slovic, 2012). Anxiety during a pandemic is elevated when there is little to no probability data accompanying absolute data in a news article (Quigley, 2020). This is the case because readers are given the consequential data without information on risk level. The most concerning discovery is the lack of probability data. It was surprising to find most articles did not inform about the risk of serious symptoms nor did it provide numerical information about the mortality rate. Additionally, the government rarely disclosed where it obtained information to make decisions. There are two reasons to speculate this was intentional. First, if much of the information came from peer-reviewed scientific articles, releasing this information could contribute to the circulation of misinformation because most people cannot read scholarly work since the language of science is meant for experts in that field. Second, it is speculated that the information provided in the evidence could induce anxiety, resulting in hysteria, and people buying an unnecessary amount of toilet paper and sanitizer. Further investigation is needed to determine whether this conjecture is correct.

In conclusion, the Canadian Broadcasting Company reported on coronavirus by using citations, absolute data, and a broad narrative to inform Canadians on decision made by the government. The results of this study show no connection between the tone of the headline and probability data, absolute data, perception of the government, or evidence-based decision making. The number of alarming versus reassuring headlines remained uniform from January to March. Only two headlines contained both reassuring and alarming connotations. In all three months the articles presented most decisions made by the government in a positive way because of the large number of citations by experts in the government and by health care professionals. Moreover, the government was transparent about where information came from to make decisions related to coronavirus.

This study does not provide conclusive evidence to suggest all CBC articles about coronavirus share the same characteristics that were found in this study. Instead, it highlights the need for future investigation on how the media perceived 
evidence-based decision making by the government during a pandemic, specifically coronavirus.

\section{References}

Burns, W. J., \& Slovic, P. (2012). Risk perception and behaviors: Anticipating and responding to a crisis. Risk Analysis, $32(4)$.

Canadian Broadcasting Company. (2020, February 15). Federal government to bring home Canadians on board quarantined cruise ship. CBC News. Retrieved from https://www.cbc.ca/news/world/coron avirus-1.5465349.

Cecco, L. (2020, March 16). "Stay home": Justin Trudeau closes Canada's borders over coronavirus. The Guardian. Retrieved from

https://www.theguardian.com/world/2 020/mar/16/justin-trudeau-closescanada-borderscoronavirus\#maincontent

Federal government to bring home Canadians quarantined cruise ship. (2020, February 15). Canadian Broadcasting Company. Retrieved from https://www.cbc.ca/news/world/coron avirus-1.5465349
Flight carrying Canadian cruise passengers who tested negative for coronavirus on way home. (2020, February 20). Canadian Broadcasting Company. Retrieved from https://www.cbc.ca/news/politics/cana dian-diamond-princess-passengerscoronavirus-flight-1.5469498

Harris, K. (2020, January 26). Health officials expect more coronavirus cases, but say risk of outbreak in Canada remains low. Canadian Broadcasting Company.

Retrieved from https://www.cbc.ca/news/politics/coro navirus-hajdu-tam-health-china1.5440950

Henry, D. J. (2013, December 16). Media and the law. The Canadian Encyclopedia. Retrieved from https://www.thecanadianencyclopedia. ca/en/article/media-and-the-law

Quigley, K. (2020, March 23). Risk psychology and COVID-19 communication challenges. The Telegram. Retrieved from https://www.thetelegram.com/opinion /regional-perspectives/kevin-quigleyrisk-psychology-and-covid-19communication-challenges-426701/

Quigley, K., Macdonald, C., \& Quigley, J. (2016). Pre-existing condition: Taking media coverage into account when preparing 
for H1N1. Canadian Public

Administration/Administration Publique

du Canada, 59(2), 267-288.

Siegrist, M., \& Zingg, A. (2014). The role of

public trust during pandemics:

Implications for crisis communication.

European Psychologist, 19(1), 23-32. 
Appendix

\section{Appendix A: articles analyzed for this} study.

The Canadian Press. (2020, January 23). Risk of new coronavirus to Canadians low, health minister says. CBC News.

Retrieved from https://www.cbc.ca/news/politics/coro navirus-risk-to-canada-low-hajdu1.5438030 .

Baker, Rafferty. (2020, January 24) Health officials ask public to stay alert, but call risk to B.C. of coronavirus spread low. CBC News. Retrieved from https://www.cbc.ca/news/canada/britis h-columbia/coronavirus-risk-low-bccdc1.5440417 .

Harris, K. (2020, January 26). Bracing for more coronavirus cases, health officials reassure public risk of outbreak remains low. CBC News. Retrieved from https://www.cbc.ca/news/politics/coro navirus-hajdu-tam-health-china1.5440950 .

Zafar, Amina. (2020, January 27). Coronavirus in Canada: What are the next steps to contain the disease here? CBC News. Retrieved from https://www.cbc.ca/news/health/coron avirus-contaminment-canada-
1.5441216.

Canadian Broadcasting Company. (2020, January 29). Air Canada suspends all flights to Beijing and Shanghai amid coronavirus outbreaks. CBC News.

Retrieved from https://www.cbc.ca/news/business/cor onavirus-air-travel-1.5444326.

Harris, K. (2020, January 30). Canada negotiates details of airlift as WHO declares global health emergency over coronavirus. $\mathrm{CBC}$ News. Retrieved from https://www.cbc.ca/news/politics/trud eau-coronavirus-airlift-china1.5446204 .

Tasker, J.P. (2020, January 31). Canada won't follow U.S. and declare national emergency over coronavirus: Health minister. CBC News. Retrieved from https://www.cbc.ca/news/politics/cha mpagne-coronavirus-airlift-china1.5447130 .

Canadian Broadcasting Company. (2020, March 08). Canada to repatriate citizens on coronavirus-hit cruise ship in California. CBC News. Retrieved from https://www.cbc.ca/news/world/covid19-coronavirus-march-8-1.5490199.

Reuters, T. (2020, February 4). WHO confirms 27 cases of new coronavirus spreading human-to-human outside of China. CBC 
News. Retrieved from

https://www.cbc.ca/news/world/who-

sends-team-china-coronavirus-

1.5451436 .

Brewster, Murray. (2020, February 6).Why it's taking so long to get Canadians out of Wuhan, and other coronavirus airlift questions. CBC News. (2020, February

6). Retrieved from

https://www.cbc.ca/news/politics/chin a-outbreak-exodus-five-things-

1.5453725 .

The Canadian Press. (2020 February 7). 5 more Canadians test positive for coronavirus aboard quarantined cruise ship. CBC News. Retrieved from https://www.cbc.ca/news/canada/britis h-columbia/coronavirus-cruise-shipcanadians-1.5455493.

The Associated Press. (2020, February 11). WHO chief says coronavirus outbreak is "public enemy No. 1.". CBC News.

Retrieved from https://www.cbc.ca/news/world/coron avirus-deaths-who-1.5459237.

Rabson, Mia. (2020, February 14). Global economic security critical, Trudeau to tell conference. CBC News. Retrieved from https://www.cbc.ca/news/politics/muni ch-security-conference-trudeau-
1.5463764 .

Canadian Broadcasting Company. (2020, February 15). Federal government to bring home Canadians on board quarantined cruise ship. CBC News. Retrieved from https://www.cbc.ca/news/world/coron avirus-1.5465349.

The Associated Press. (2020, February 18). Canadians wait for flight home as COVID-19 numbers rise on quarantined ship. CBC News. Retrieved from https://www.cbc.ca/news/world/coron avirus-covid-19-china-japan-canadians1.5466808 .

Canadian Broadcasting Company. (2020, February 20). Flight carrying Canadian cruise passengers who tested negative for coronavirus on way home. $\mathrm{CBC}$ News. Retrieved from https://www.cbc.ca/news/politics/cana dian-diamond-princess-passengerscoronavirus-flight-1.5469498.

Harris, K. (2020, February 26). Canada preparing a Plan B pandemic response in case coronavirus containment fails. CBC News. Retrieved from https://www.cbc.ca/news/politics/coro navirus-iran-champagne-repatriation1.5476434 .

Harris, K. (2020, February 29). What's next for 
Canada if the WHO calls COVID-19 a

pandemic? CBC News. Retrieved from

https://www.cbc.ca/news/politics/coro

navirus-covid19-tam-pandemic-

preparations-1.5480034.

Miller. A. \& Zafar, A. (2020, March 12). What the decision to call the COVID-19 outbreak a pandemic means for Canada and the world. CBC News. Retrieved from https://www.cbc.ca/news/health/coron avirus-pandemic-canada-world1.5494605 .

(2020, March 15). Coronavirus: What's happening in Canada and around the world March 15 / CBC News. CBC. https://www.cbc.ca/news/canada/coro navirus-covid19-march-15-canadaworld-1.5498348

Canadian Broadcasting Company. (2020, March 16). "No gatherings of over 50" among new recommendations announced by officials to curb spread of COVID-19. CBC News. Retrieved from https://www.cbc.ca/news/canada/toro nto/ontario-covid-19-coronavirusmonday-1.5498849.

Gollom, Mark. (2020, March 17). Justin Trudeau is asking Canadians abroad to come home now. It's not that easy. CBC News. Retrieved from https://www.cbc.ca/news/canada/coro navirus-outbreak-flights-canadiansabroad-return-1.5498961.

Nanowski, N. (2020, March 18). Big banks promise mortgage help for Canadians as Ottawa set to announce $\$ 25 B$ in COVID-19 relief. CBC News. Retrieved from

https://www.cbc.ca/news/canada/toro nto/mortgage-covid19-coronaviruscmhc-stimulus-1.5501125.

Wherry, A. (2020, March 24). Lives are at stake - so why are some Canadians ignoring social distancing rules? CBC News. Retrieved from https://www.cbc.ca/news/politics/trud eau-covid-19-coronavirus-pandemicsocial-distancing-1.5507379.

Tasker, J.P. (2020, March 25). Parliament passes Ottawa's \$107 billion COVID-19 aid package. CBC News. Retrieved from https://www.cbc.ca/news/politics/covi d19-coronavirus-ottawa-hill-economiclegislation-1.5509178.

Jones, R. P. (2020, March 29). Top public health officer says coming week a crucial period in COVID-19 struggle / CBC News. (n.d.). Retrieved April 14, 2020, from https://www.cbc.ca/news/politics/nextweek-crucial-coronavirus-1.5514242. 
Patel, R. (2020, March 29). Trudeau pledges more help for vulnerable Canadians struggling with coronavirus crisis. $\mathrm{CBC}$ News. Retrieved from https://www.cbc.ca/news/politics/trud eau-announces-more-help-forvulnerable-canadians-1.5514055. 
Appendix B: Uncoded descriptors of $\mathrm{CBC}$ articles

\section{Stage 2: Non-coded Descriptors}

Information from the Raw Data Excel sheets for each month were simplified in order to add codes to the articles.

\section{CBC-JAN-1}

- Headline is reassuring

- Probability data: minimal risk mentioned; present through self calculation

- Absolute data stated I broader context

- Portrayal of government is positive

- Direct quotes from: health minister, PM of Canada

- Indirect quotes from chief public health minister

\section{CBC-JAN-2}

- Headline is more alarming than reassuring

- Probably data: risk mentioned

- Absolute data in broad context

- Portrayal of government is mixed but positive tone stronger

- Direct quote from health minister, FAM
CBC-JAN-3 was excluded from this study

\section{CBC-JAN-4}

- Headline is more reassuring than alarming

- Probability data through self calculation, mentioned minimal risk

- Absolute data in broad context

- Portrayal of government in positive tone

- Quote: Dr. Danuta Skowronski

\section{CBC-JAN-5}

- Headline is objective

- Probability data provided, mentioned minimal risk

- Absolute data in broad context

- Portrayal of government is positive

- Direct quote from WHO, Dr. Allison Mcgreer

- Indirect quote from FAM

\section{CBC-JAN-6}

- Headline is negative

- Probability neglect

- Absolute neglect

- Broad context 
- Portrayal of government in positive tone

- $\quad$ Direct quote from FAM, Global affairs Canada

CBC-JAN-7 was excluded from this study

\section{CBC-Jan-8}

- Headline is alarming

- Probability data through self calculation, mentions low risk

- Absolute data in broad context

- Portrayal of government is positive

- Indirect comment from health officials in Canada

\section{CBC-JAN-9}

- Headline is equally reassuring and alarming

- Probability data mentioned minimal risk for Canadians

- Absolute data in broad context

- Little focus on individual

- Portrayal of government is positive

- Direct quotes from Health minister, Dr. Jerome Leis, FAM
- Indirect quotes from chief public health officer, CDC, deputy chief public health officer, transport minister

\section{CBC-JAN-10}

- Headline is alarming

- Probability data mentioned minimal risk

- Absolute data in broad context

- $\quad$ Little focus on individual

- Portrayal of government is positive

- Direct quote from Ontario chief medical officer, chief medical officer, Dr. Andrew Morris

\section{CBC-FEB-1}

- Headline is reassuring

- Probability neglect

- absolute data stated in a broader context

- little focus on individuals abroad

- Portrayal of government is mixed but the positive tone is stronger

- No direct citations were made

- Commentary from health minister and Foreign Affairs Minister

\section{CBC-FEB-2}

- Headline is alarming 
- Probability data present through self calculation

- Absolute data stated in a broader context

- Portrayal of government is mixed but the negative tone is stronger

- $\quad$ No direct citation from government; commentary from foreign affairs minister

\section{CBC-FEB-3}

- Headline is alarming

- Probability neglect

- absolute data stated in a broader context

- $\quad$ Few comments from sick individuals abroad

- Portrayal of government is positive

- $\quad$ Direct quotes from WHO

\section{CBC-FEB-4}

- Headline is reassuring

- Probability data present through self calculation

- Absolute data stated in broader context

- $\quad$ Few commentaries from Canadians abroad

- Portrayal of government is positive
- $\quad$ Direct quote from FAM, health minister and defence minister

\section{CBC-FEB-5}

- Headline is objective

- Probability neglect

- Absolute data stated in broader context

- Portrayal of the government is positive

- Direct quote from: deputy PM, chief public health officer, medical officer,

- Indirect quote from FAM

\section{CBC-FEB-6}

- Headline is alarming

- Probability neglect

- $\quad$ Absolute data in broader context

- Portrayal of government is negative

- Direct quote from health minister, FAM, surgeon-general of military

\section{CBC-FEB-7 was excluded from this study}

\section{CBC-FEB-8 was excluded from this study}

\section{CBC-FEB-9}

- Headline is positive

- Probability data: minimal risk mentioned

- $\quad$ Absolute data in broader context 
- Portrayal of government is mixed, undetermined tone**

- Direct quote from chief public health

officer, FAM, Iranian Canadian

Congress, health minister, Public health agency of Canada

\section{CBC-FEB-10}

- Headline is negative

- Probability data present through self calculation

- Absolute data stated in a broader context

- Commentary from individuals

- Portrayal of government is positive

- Direct quote from doctor

\section{CBC-MAR-1}

- Headline is positive

- Probability data present through self calculation

- Absolute data stated in a broader context

- Little focus on individuals

- Portrayal of government is positive

- Direct quotes from global affairs, VP of Grand Princess cruise ship, U.S. department of Health and Human services, medical officer

\section{CBC-MAR-2}

- Headline is objective

- Probability data is stated

- Absolute data stated in a broader context

- $\quad$ Little focus on individuals

- Portrayal of government is positive

- Direct quote from Prime Minister of Canada (PM of Canada), and Canadian public health officials

- Indirect quotes from premier of Ontario and premier of Quebec

\section{CBC-MAR-3}

- Headline is negative

- Probability neglect

- No Absolute data

- $\quad$ Article context

- Little focus on individual

- Portrayal of government is positive

- $\quad$ Direct quote from WHO, Dr. Michael Gardam (scientists), Dr. Jason Mindrachuk (scientist), Dr. Isaac Bogoch (scientist)

\section{CBC-MAR-4}

- Headline is positive 
- Probability neglect

- No absolute data

- Broad context

- Portrayal of government is mixed tone, positive tone is stronger

- Direct quote from transport minister, PM of Canada, Families, Children and social development minister

\section{CBC-MAR-5}

- Headline is negative

- Probability neglect

- Absolute data is broader context

- Portrayal of government is negative

- $\quad$ Direct quote from PM of Canada

\section{CBC-MAR-6 was excluded from this study}

\section{CBC-MAR-7}

- Headline is negative

- Probability data present through self calculation

- Absolute data in broad context

- Portrayal of government is positive

- Direct quote: Health Minister, PM of Canada

\section{CBC-MAR-8}

- Headline is positive

- Probability neglect
- No absolute data

- Broader context

- Portrayal of government is positive

- Direct quote from CMHC CEO, PM of Canada

\section{CBC-MAR-9}

- Headline is positive

- Probability neglect

- No absolute data

- Broader context

- Portrayal of government is undetermined

- Direct quote from conservative senate leader

- Indirect quote from CMHC CEO

- PM of Canada

\section{CBC-MAR-10}

- Headline is negative

- Probability neglect

- Absolute neglect

- Individual context

- Little focus on broader context

- Portrayal of government is negative

- Indirect comment from PM of Canada 
Appendix C: Code Legend

\begin{tabular}{|c|c|}
\hline \multicolumn{2}{|c|}{ Tone of Headline $(\mathrm{H})$} \\
\hline H-RSR & Headline is reassuring \\
\hline H-ALM & Headline is alarming \\
\hline H-ALR & $\begin{array}{l}\text { Headline is more alarming than } \\
\text { reassuring }\end{array}$ \\
\hline H-RSA & $\begin{array}{l}\text { Headline is more reassuring than } \\
\text { alarming }\end{array}$ \\
\hline $\mathrm{H}-\mathrm{OBJ}$ & $\begin{array}{l}\text { Headline is objective, neither } \\
\text { reassuring nor alarming }\end{array}$ \\
\hline H-EQU & $\begin{array}{l}\text { Headline is equally reassuring and } \\
\text { alarming }\end{array}$ \\
\hline \multicolumn{2}{|c|}{ Probability data (P) } \\
\hline P-NGT & Probability neglect \\
\hline P-CAL & $\begin{array}{l}\text { Probability data is present, but } \\
\text { readers must do the calculations } \\
\text { themselves }\end{array}$ \\
\hline P-MIN & $\begin{array}{l}\text { Probability data is not present, } \\
\text { comments are made about minimal } \\
\text { risk }\end{array}$ \\
\hline P-STT & Probability data is stated \\
\hline \multicolumn{2}{|c|}{ Absolute data, information context (A) } \\
\hline A-BRD & $\begin{array}{l}\text { Absolute data stated in a broader } \\
\text { context }\end{array}$ \\
\hline A-IDV & $\begin{array}{l}\text { Absolute data stated in an } \\
\text { individual context }\end{array}$ \\
\hline
\end{tabular}

\begin{tabular}{|c|c|}
\hline A-IMI & Little focus on individuals \\
\hline A-IMA & $\begin{array}{l}\text { Quotes or commentary from } \\
\text { individuals }\end{array}$ \\
\hline A-NDB & No absolute data; broader context \\
\hline A-NDI & $\begin{array}{l}\text { No absolute data; individual } \\
\text { context }\end{array}$ \\
\hline A-LCO & Little focus on broader context \\
\hline \multicolumn{2}{|c|}{ Perception of government (G) } \\
\hline G-NEG & $\begin{array}{l}\text { Portrayal of government in a } \\
\text { negative tone }\end{array}$ \\
\hline G-POS & $\begin{array}{l}\text { Portrayal of government in a } \\
\text { positive tone }\end{array}$ \\
\hline G-MXN & $\begin{array}{l}\text { Portray of government uses mixed } \\
\text { tones, but negative tone is stronger }\end{array}$ \\
\hline G-MXP & $\begin{array}{l}\text { Portrayal of government uses } \\
\text { mixed tones, but positive tone is } \\
\text { stronger }\end{array}$ \\
\hline G-UDE & $\begin{array}{l}\text { Portrayal of government is } \\
\text { undetermined }\end{array}$ \\
\hline \multicolumn{2}{|c|}{ Citations (D/I) } \\
\hline D-ACD & $\begin{array}{l}\text { Direct quote from anyone who is an } \\
\text { academic at a university }\end{array}$ \\
\hline N-ACD & $\begin{array}{l}\text { Indirect quote from anyone who is } \\
\text { an academic at a university }\end{array}$ \\
\hline $\mathrm{D}-\mathrm{SCl}$ & $\begin{array}{l}\text { Direct quote from a scientist, non- } \\
\text { government health professionals }\end{array}$ \\
\hline
\end{tabular}




\begin{tabular}{|c|c|}
\hline $\mathrm{N}-\mathrm{SCl}$ & $\begin{array}{l}\text { Indirect quote from a scientist, non- } \\
\text { government health professional }\end{array}$ \\
\hline D-HLT & $\begin{array}{l}\text { Direct quote from federal } \\
\text { government(health) }\end{array}$ \\
\hline $\mathrm{N}-\mathrm{HLT}$ & $\begin{array}{l}\text { Indirect quote from federal } \\
\text { government (health) }\end{array}$ \\
\hline D-MIL & $\begin{array}{l}\text { Direct quote from federal } \\
\text { government(military) }\end{array}$ \\
\hline N-MIL & $\begin{array}{l}\text { Indirect quote from federal } \\
\text { government (military }\end{array}$ \\
\hline D-IRE & $\begin{array}{l}\text { Direct quote from federal } \\
\text { government } \\
\text { relations) }\end{array}$ \\
\hline N-IRE & $\begin{array}{l}\text { Indirect quote from federal } \\
\text { government } \\
\text { relations) }\end{array}$ \\
\hline D-WHO & Direct quote from $\mathrm{WHO}$ \\
\hline N-WHO & Indirect quote from $\mathrm{WHO}$ \\
\hline D-OTH & Direct quote from others* \\
\hline $\mathrm{I}-\mathrm{OTH}$ & Indirect quote from others* \\
\hline
\end{tabular}

workers that do not fall under health, military, or international relations.

*This includes U.S. department of Health and Human Services, U.S. Center for Disease and Control Prevention, Vice President of Grand Princess cruise ship, and provincial premiers, Canadian Mortgage and Housing Corporation (CMHC) CEO, other Canadian government 